\title{
KESIAPAN KOTA MADIUN TERHADAP PENERAPAN KONSEP KOTA KREATIF GASTRONOMI
}

\author{
Devy Herawati ${ }^{1}$, Winny Astuti ${ }^{1}$, Erma Fitria Rini ${ }^{1}$ \\ ${ }^{1}$ Program Studi Perencanaan Wilayah dan Kota Fakultas Teknik Universitas Sebelas Maret
}

\begin{abstract}
Abstrak
Kota Madiun yang sering dikenal dengan kota pecel, merupakan kota yang memiliki potensi besar di bidang kuliner. Industri kuliner merupakah salah satu aktivitas ekonomi utama masyarakat di Kota Madiun. Potensi tersebut mendorong Pemerintah Kota Madiun untuk menerapkan konsep kota kreatif gastronomi di Kota Madiun. Hal tersebut juga didorong oleh peran Kota Madiun sesuai yang telah direncanakan oleh Pemerintah Jawa Timur sebagai hinterland atau pusat aktivitas ekonomi untuk daerah sekitarnya. Namun dalam persiapannya masih ada kendala yang dihadapi. Tujuan penelitian ini yaitu untuk menganalisis kesiapan Kota Madiun terhadap penerapan konsep kota kreatif gastronomi. Penelitian ini menggunakan metode kuantitatif dengan analisis skoring skala Likert. Analisis skoring dilakukan pada masing-masing parameter. Hasil analisis menunjukkan bahwa Kota Madiun termasuk dalam kategori cukup siap untuk diterapkan konsep kota kreatif gastronomi. Hal ini diketahui dari adanya beberapa variabel yang termasuk dalam kategori siap, yaitu industri kreatif dan komunitas kreatif. Hasil akhir penelitian yang didapatkan menyatakan bahwa ketidaksiapan variabel-variabel tersebut disebabkan oleh kurangnya dukungan pemerintah dan pelaku industri untuk menciptakan lingkungan kota yang mampu mengembangkan ide-ide penduduk Kota Madiun dalam penerapan konsep kota kreatif gastronomi.
\end{abstract}

Kata kunci: gastronomi; kesiapan; kota kreatif; kota kreatif gastronomi

\begin{abstract}
Madiun City is known as the town of Pecel. It is a city that has a great potential in culinary industry. The culinary industry is one of the main economic activities of the community in Madiun. That potential encourages the Government to apply the gastronomy creative city concept for the City's Development Concept. The plan to boosting the city's development is also influenced by the role of Madiun as the center of economic activity for its surrounding regions. However, developing Madiun as the gastronomy creative city is not that easy, asthere are several obstacles faced by the government. The aim of this research is to analysis the preparedness of Madiun City through application of the gastronomy creative city concept. This study used quantitative methods with Likert Scale. Scroing was performed on each parameter of gastronomy creative city. The results indicate that the Madiun City is categorized as relatively ready to apply the gastronomy creative city concept. It is mainly because of the support of creative industry and creative community, while lacking of government support and industry players to create an environment that can flourish the creaive ideas of its community to support the the implementation of the gastronomy creative city concept are stil lacking.
\end{abstract}

Keywords: creative city, gastronomy, gastronomy creative city, readiness

\section{PENDAHULUAN}

Kota kreatif merupakan kota yang lingkungan mampu memfasilitasi seseorang untuk memikirkan, merencanakan, dan bertindak dengan imajinasi dalam memanfatkan kesempatan menjadi pemecahan suatu masalah (Landry, 2000). Parameter yang dapat dijadikan sebagai tolak ukur dalam mengkategorikan suatu kota berpotensi menjadi kota kreatif adalah dengan ketiga hal berikut: potensi ekonomi kreatif (creative economy), individu atau golongan kreatif (creative class), dan pengembangan dan perencanaan lingkungan kreatif (creative milieu) (Landry, 2006). Berdasarkan UNESCO Creative Cities Network (UCCN) ada 7 bidang kota kreatif, yaitu Kriya dan Seni Rakyat, Desain, Film, Gastronomi, Sastra, Media Arts dan Musik. 
Gastronomi adalah sebuah studi mengenai hubungan antara budaya dan makanan, dimana gastronomi mempelajari berbagai komponen budaya dengan makanan sebagai pusatnya (Gilleisole, 2001). Menurut UNESCO ada 9 kriteria kota kreatif gastronomi antara lain: adanya satu atau banyak industri kuliner; kontribusi industri kuliner terhadap pembangunan ekonomi dan penyerapan tenaga kerja di kota, pengetahuan masyarakat terkait industri kuliner dalam sejarah kota; adanya festival dan acara skala besar lainnya yang diselenggarakan terkait industri kuliner; adanya sekolah kejuruan maupun kursus di bidang kuliner; ketersediaan fasilitas untuk pendukung pengembangan industri kuliner; adanya kebijakan, program dan kerjasama yang dilakukan oleh kota untuk mengembangkan dan mempromosikan industri kuliner; adanya kelompok-kelompok masyarakat yang aktif dalam pengembangan dan mempromosikan industri kuliner; kemudahan pemanfaatan bahan baku lokal.

Kota Madiun terkenal dengan slogan sebagai Kota Pecel hal ini dikarenakan besarnya potensi Kota Madiun di bidang kuliner, khususnya sambel pecel. Dinas Perindustrian, Perdagangan Koperasi dan Pariwisata Kota Madiun mengembangkan produk unggulan industri-industri kreatif di Kota Madiun khususnya yang pada industri kuliner yaitu industri sambal pecel, madumongso dan kerupuk puli. Pengembangan dilakukan dengan memberi pembinaan, promosi dan pelatihan secara berkala. Untuk modal, Disperindagkoppar Kota Madiun bekerjasama dengan sejumlah bank agar memberikan pinjaman dengan bunga ringan. Berdasarkan data Disperindagkoppar Kota Madiun tahun 2015, industri makanan mampu menyerap 355 tenaga kerja $(34,98 \%)$. Dilihat dari nilai produksi, klasifikasi industri makanan menduduki peringkat pertama dengan nilai 11 miliar rupiah. Selain itu terdapat $41 \mathrm{IKM}$ pengolahan sambal pecel yang masih eksis di Kota Madiun. Rata-rata produksinya adalah $50 \mathrm{~kg}$ sampai dengan 1 ton sambal pecel tiap bulannya dengan jumlah karyawan sekitar 150 orang (KOMINFO JATIM, 2015). Dengan potensi-potensi yang dimiliki Kota Madiun di bidang industri kuliner, Wali Kota Madiun Bambang Irianto mengeluarkan statement bahwa Kota Madiun akan menuju ke konsep kota kreatif dengan potensi unggulan di bidang kuliner (Wibisono, 2015). Hal tersebut juga didorong oleh peran Kota Madiun sesuai yang telah direncanakan oleh Pemerintah Jawa Timur sebagai hinterland atau pusat aktivitas ekonomi untuk daerah sekitarnya.

Namun masih terdapat beberapa masalah terkait pengembangan konsep kota kreatif gastronomi, di antaranya adalah masyarakat Kota Madiun dan luar Kota Madiun masih banyak yang belum mengetahui kuliner lokal Kota Madiun selain sambel pecel, hal ini dikarenakan kurangnya penyelenggaraan event/pameran kuliner untuk mempromosikan produk kuliner khas Kota Madiun, ketersediaan bahan baku lokal yang masih rendah, masih kurangnya modal dan akses pembiayaan, masih belum tersedianya ruang pamer hasil industri kuliner, dan masih kurangnya fasilitasi kerjasama pelaku industri kuliner di Kota Madiun dengan pelaku usaha yang berskala besar (KIM Bhakti Pertiwi, 2016).

Oleh karena itu, peneliti mengkaji kesiapan Kota Madiun terhadap penerapan konsep kota kreatif gastronomi untuk mengetahui apakah Kota Madiun telah siap diterapkan konsep kota kreatif gastronomi dalam pengembangan kotanya yang mampu menjadikan Kota Madiun sebagai pusat ekonomi daerah sekitarnya.

\section{KAJIAN LITERATUR}

Kota kreatif merupakan kota yang lingkungan mampu memfasilitasi seseorang untuk memikirkan, merencanakan, dan bertindak dengan imajinasi dalam memanfatkan kesempatan menjadi pemecahan suatu masalah (Landry, 2000). Menurut Landry (2000), salah satu yang penting dalam kota kreatif adalah keberadaan "piranti keras" (infrastruktur) dan "piranti lunak" (tenaga kerja yang dinamis, fleksibel dan memiliki kemampuan tinggi. Komponen kota kreatif adalah unsur-unsur atau bagian yang terdapat dalam kota kreatif. Berdasarkan hasil kajian literatur, terdapat beberapa komponen yang menunjang kota kreatif, (Landry,2006), Evans (2009), Vickery (2011), Pratt (2008): (1) Industri kreatif; (2) Komunitas kreatif; (3) Lingkungan kreatif; (4) Kebijakan; dan (5) Kebudayaan lokal. Dimana komponen tersebut merupakan sistem yang setara dan saling melengkapi. Menurut Landry (2006) untuk menjadi sebuah kota kreatif ada beberapa hal yang dapat dilaksanakan oleh sebuah kota guna menciptakan lingkungan dan atmosfir yang kreatif, antara lain: (1) Keberagaman dan bakat yang bervariasi; (2) Individu kreatif; (3) Ruang kreatif dan fasilitas; (4) Identitas lokal; (5) Partisipasi masyarakat; (6) Kemitraan; dan (7) Kebijakan.

Gastronomi atau tata boga merupakan seni atau ilmu makanan yang baik (good eating) (Gilleisole, 2001). Menurut UNESCO (2004) ada 9 kriteria kota kreatif gastronomi/kuliner antara lain: (1) Adanya satu atau banyak industri kuliner yang sudah mapan; (2) Kontribusi industri kuliner terhadap pembangunan ekonomi dan penyerapan tenaga kerja di kota; (3) Adanya sejarah kota di bidang kuliner; (4) Adanya festival dan acara skala besar lainnya yang diselenggarakan terkait industri kuliner; 
(5) Adanya sekolah kejuruan maupun kursus di bidang kuliner; (6) Ketersediaan fasilitas untuk pendukung pengembangan kota kreatif gastronomi. Fasilitas yang dimaksud adalah pasar tradisional, restoran tradisional, dan pusat oleh-oleh makanan tradisional; (7) Adanya rencana, program dan kerjasama yang dilakukan untuk mengembangkan kota kreatif gastronomi; (8) Adanya kelompok-kelompok masyarakat yang aktif dalam pengembangan kota kreatif gastronomi; (9) Kemudahan pemanfaatan bahan baku lokal.

\section{METODE PENELITIAN}

Berdasarkan karakteristik penelitian, pendekatan yang digunakan dalam penelitian ini yaitu pendekatan kuantitatif, data yang diolah merupakan data numerik yang menggunakan perhitungan statistik. Teknik pengumpulan data yang digunakan dalam penelitian ini yaitu:

a) Studi dokumen, dilakukan dengan meminta data kepada dinas terkait. Adapun data yang diminta adalah jumlah dan persebaran industri kuliner di Kota Madiun, jumlah lapangan kerja industri kreatif kuliner dan jumlah lapangan kerja total, jumlah tenaga kerja sektor industri kreatif desain dan jumlah pekerja sektor industri; jumlah penduduk berdasarkan usia; jumlah dan persebaran restoran, pasar tradisional, pusat oleh-oleh, tempat pelatihan, taman dan museum; rencana mengembangkan industri kreatif kuliner, komunitas kreatif (SDM), lingkungan kreatif, wisata budaya; dan kerjasama antar pemerintah, pelaku industri dan pihak ketiga dari Dinas Perdagangan dan Perindustrian serta Dinas Tata Ruang Kota Madiun.

b) Pengamatan langsung, berupa pengamatan terhadap lokasi-lokasi industri kuliner, pengamatan terhadap ruang-ruang kreatif (fasilitas pemasaran dan pengembangan), dan traffic counting. Dalam teknik ini observasi yang dilakukan dengan menggunakan borang observasi berupa check list data yang dibutuhkan. Observasi dilakukan untuk mengidentifikasi serta memverifikasi lokasi-lokasi industri kreatif kuliner dan ruang kreatif di Kota Madiun.

c) Wawancara, yang dilakukan adalah wawancara terstruktur dengan responden dinas-dinas terkait pengembangan kota kreatif (Dinas Tata Ruang, Dinas Perdagangan, Perindustrian dan Pariwisata, serta BAPPEDA) untuk menanyakan seputar rencana pengembangan kota kreatif gastronomi di Kota Madiun; jumlah kelompok masyarakat, lembaga pemerintah dan swasta dalam pengembangan kota kreatif gastronomi; kerjasama antara tiga pihak (public, private dan voluntary); sejarah kota terkait industri kuliner; dan jumlah penyelenggaraan event kuliner pada tingkat lokal, nasional dan internasional. Selain dinas, responden dari wawancara yang dilakukan adalah pelaku industri. Adapun data yang ingin didapatkan adalah paguyuban industri kuliner; dan partisipasi pelaku industri dalam penyelenggaraan event.

d) Kuesioner, dilakukan untuk mengetahui alur rantai produksi; paguyuban masyarakat di bidang kuliner lokal; jumlah penduduk lokal yang bekerja sebagai pelaku industri; dan partisipasi masyarakat dalam penyelenggaraan event kuliner. Dalam teknik ini terlebih dahulu dilakukan pembuatan instrumen survei yang berupa daftar pertanyaan berdasarkan indikator variabel, lalu kuesioner tersebut disebar ke pelaku industri kreatif kuliner.

Teknik analisis yang digunakan adalah analisis skoring Likert terhadap tiap parameter yang menjadi input. Analisis skoring Likert adalah analisis yang digunakan untuk mengukur sikap, persepsi atau pendapat seseorang atau kelompok mengenai suatu peristiwa atau fenomena sosial. Setiap jawaban yang menggunakan skala likert mempunyai gradasi dari positif sampai negatif (Sugiyono, 2015). Masing-masing indikator ditentukan dulu parameternya dengan membagi parameter menjadi 3, yaitu siap, cukup siap dan tidak siap. Parameter dari indikator tersebut didapatkan dari teori maupun pendekatan lainnya, seperti asumsi maupun berdasarkan penelitian sebelumnya. operasional variabel yang digunakan dalam penelitian dapat dilihat pada Tabel 1. 
Desa-Kota, Vol. 2, No. 2, 2020, 143-157

Tabel 1. Operasional Variabel

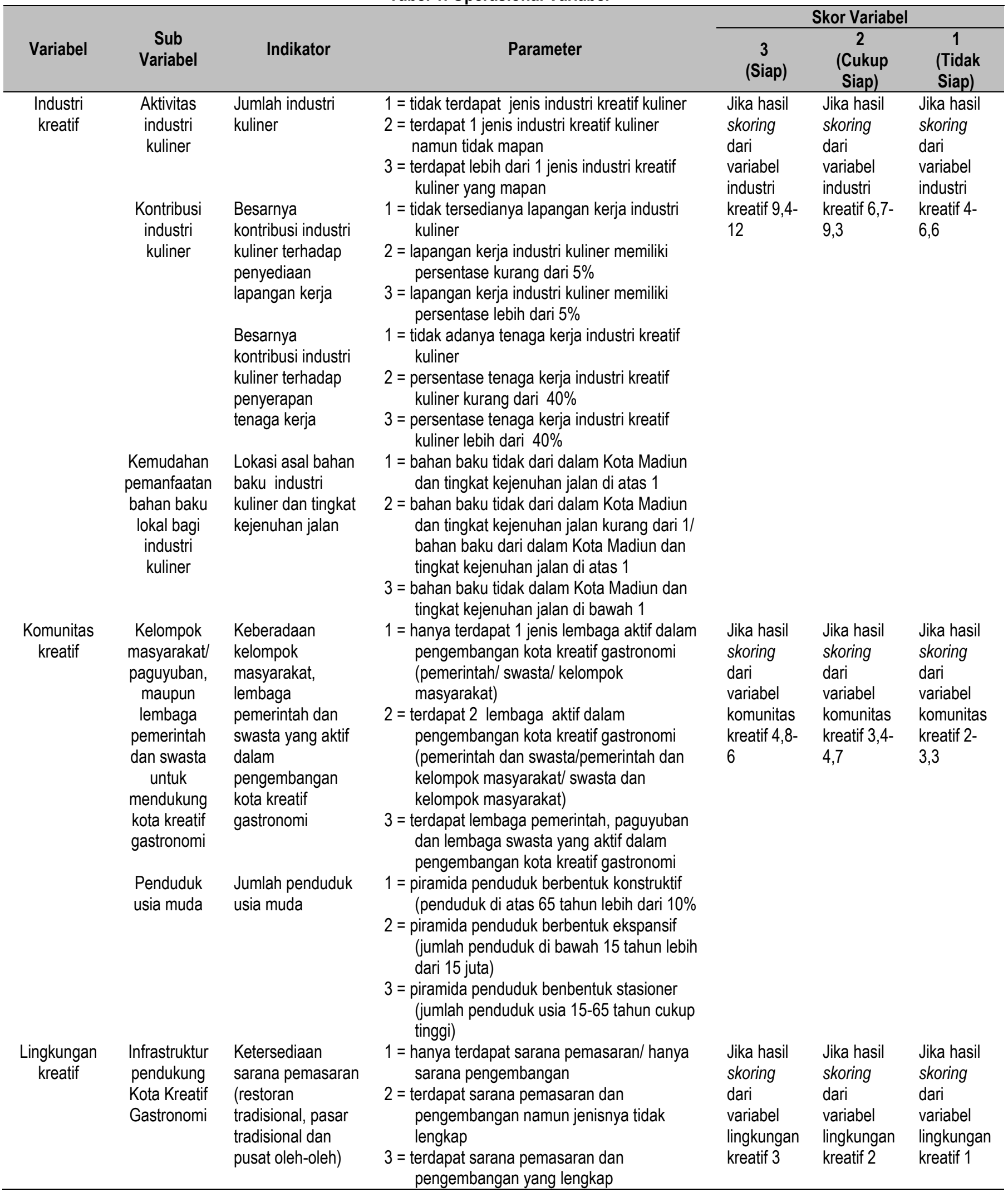


Desa-Kota, Vol. 2, No. 2, 2020, 143-157

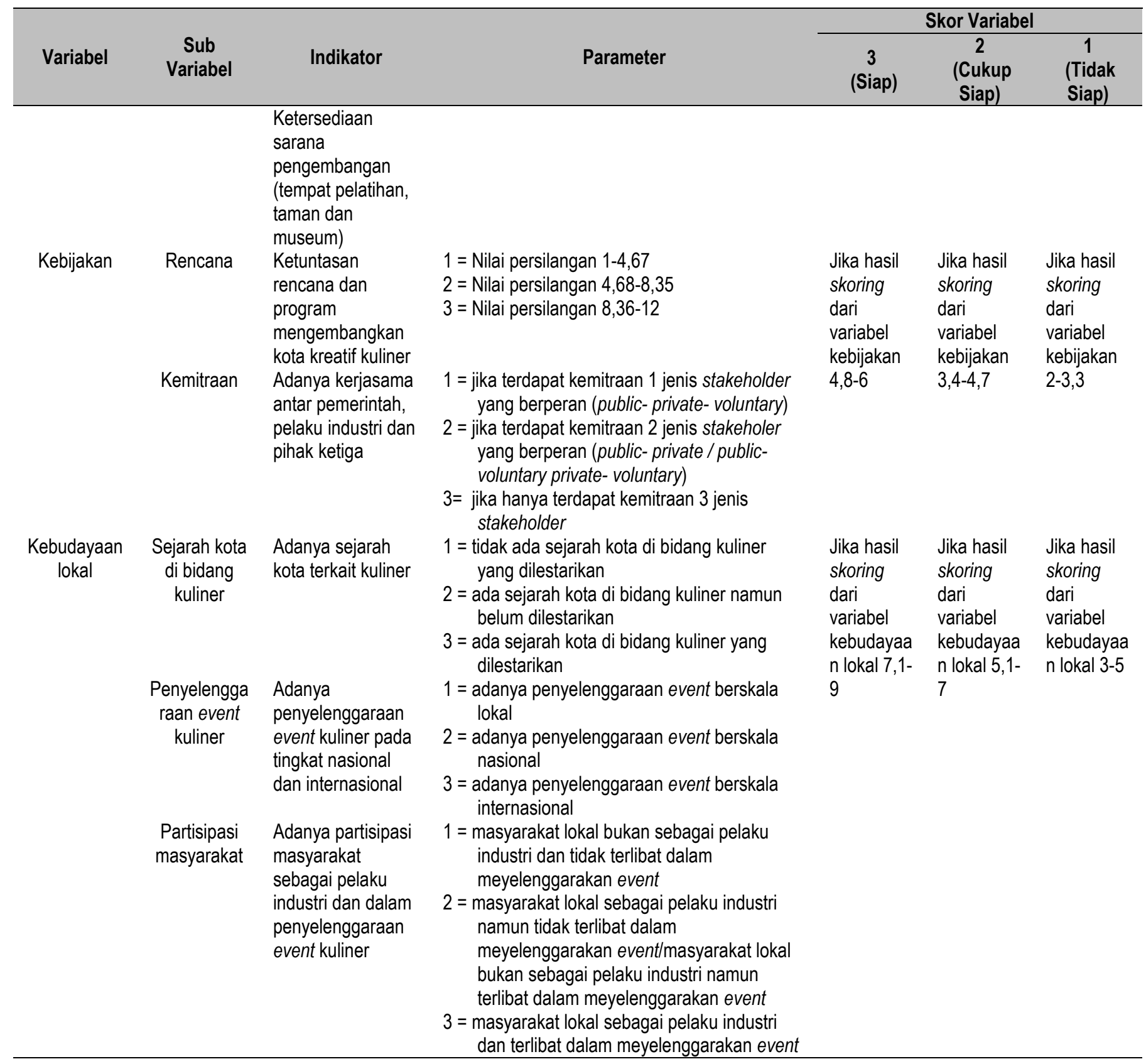

Setelah didapatkan hasil skoring pada masing-masing variabel, kemudian dilakukan analisis keseluruhan untuk mengetahui kesiapan Kota Madiun dalam penerapan konsep kota kreatif gastronomi. Untuk mengetahui Kota Madiun sebagai kota kreatif gastronomi termasuk dalam kategori siap, cukup siap atau tidak siap, dilakukan penjumlahan nilai maksimal dan nilai minimal, lalu dilanjutkan dengan mencari interval. Nilai maksimal adalah 15 yang didapatkan dari hasil perkalian skor tertinggi (3) dengan jumlah variabel (5), sedangkan nilai minimal adalah 5 yang didapat dari perkalian skor terendah (1) dengan jumlah variabel (5). Setelah didapatkan niali maksimal dan nilai minimal, dilanjutkan dengan menententukan interval.

$$
\begin{aligned}
\text { Interval } & =\frac{\text { Nilai } \text { max }- \text { Nilai } \text { min }}{\text { Jumlah kelas }} \\
& =\frac{15-5}{3} \\
& =3,33
\end{aligned}
$$


Setelah diperoleh nilai interval, maka dapat diketahui hasil skoring keseluruhan variabel untuk mengetahui kesiapan penerapan konsep kota kreatif gastrnomi sebagai berikut:

Keterangan:

$\begin{array}{ll}5-8,3 & =\text { Tidak siap } \\ 8,4-11,7 & =\text { Cukup } \\ 11,8-15 & =\text { Siap }\end{array}$

\section{HASIL DAN PEMBAHASAN}

Berdasarkan hasil analisis, dalam hal ini akan dijabarkan mengenai pembahasan dari hasil analisis skoring tiap varibel. Berikut ini merupakan penabaran dari hasil analisis:

\subsection{KESIAPAN INDUSTRI KREATIF}

\subsubsection{Kesiapan Aktivitas Industri Kuliner}

Kesiapan aktivitas industri kuliner yang dimiliki oleh kota kreatif gastronomi dapat dilihat dari adanya lebih dari satu jenis industri kuliner yang telah mapan (UNESCO, 2004). Menurut Chengdu City of Gastronomy (2012), kesiapan kota kreatif dilihat dari keberadaan industri kuliner yang menjadi ikon kota.

Industri kuliner di Kota Madiun yang termasuk dalam kategori mapan terdapat tiga jenis, yaitu 43 industri sambel pecel, 5 industri madumongso dan 7 industri kerupuk puli. Setiap bulannya industri sambel pecel mampu memproduksi sekitar $50 \mathrm{~kg}$ hingga 1 ton sambel pecel. Industri madumongso tiap bulannya mampu memproduksi $50 \mathrm{~kg}$ hingga $400 \mathrm{~kg}$, dan industri kerupuk puli $150 \mathrm{~kg}$ hingga $300 \mathrm{~kg}$ setiap bulannya. Jika memasuki Bulan Ramadhan dan Bulan Syawal, permintaan terhadap ketiga produk tersebut meningkat sehingga jumlah produksi tiap bulannya juga meningkat hingga mencapai 100\%. Sehingga Kota Madiun termasuk dalam kategori siap. Gambar 1 adalah peta persebaran lokasi industri kuliner khas di Kota Madiun:

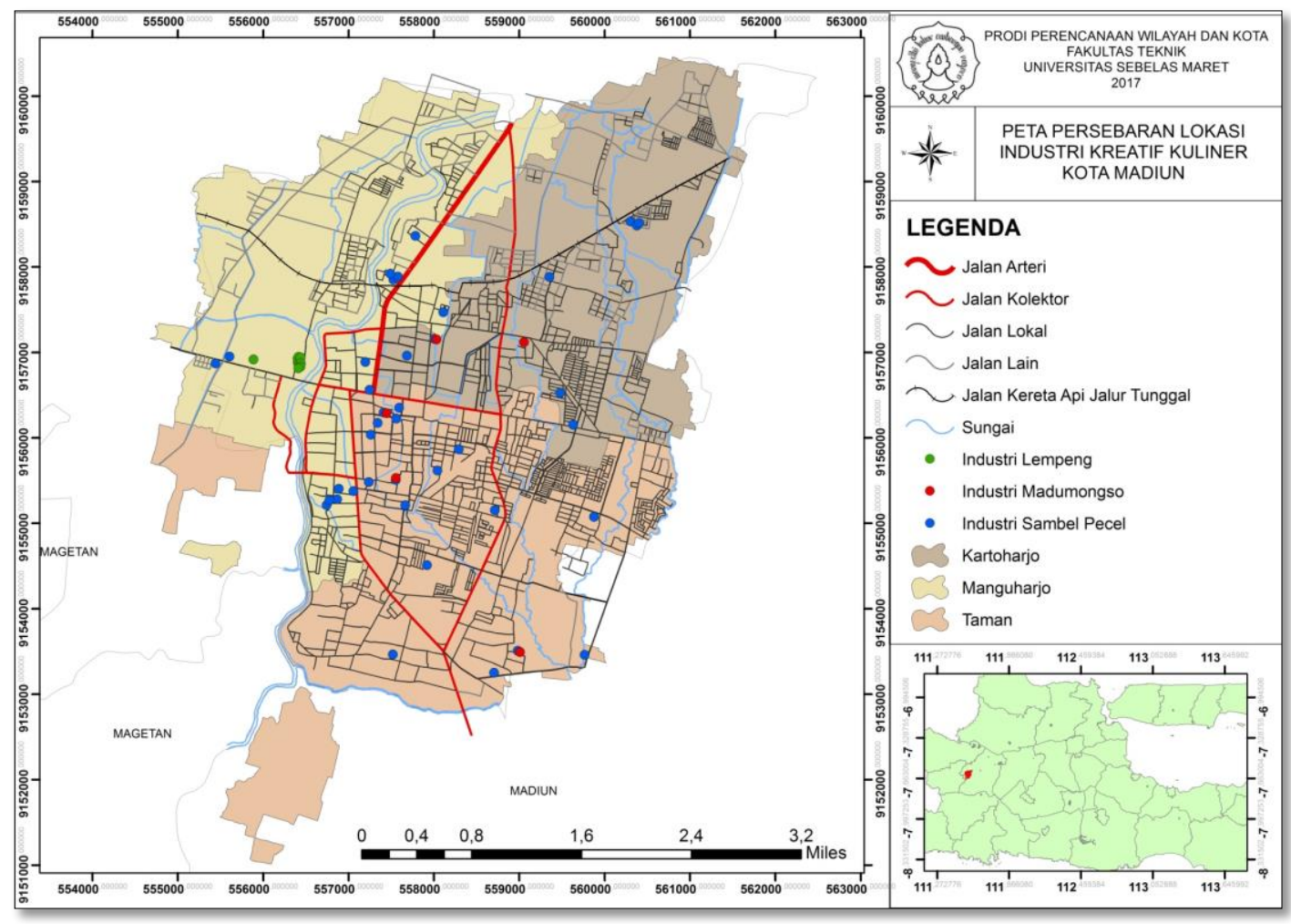

Gambar 1. Peta Persebaran Industri Kreatif Subsektor Kuliner di Kota Madiun 


\subsubsection{Kesiapan Kontribusi Industri Kuliner}

Kesiapan kontribusi industri kuliner dilihat dari dua hal, yaitu kotribusi industri kuliner terhadap penyediaan lapangan kerja dan kontribusi industri kuliner terhadap penyerapan tenaga kerja (UNESCO, 2004). Suatu kota dapat disebut siap dalam penerapan konsep kota kreatif gastronomi apabila persentase penyediaan lapangan kerja sub sektor industri kuliner lebih dari $5 \%$ dari total jumlah lapangan kerja sektor industri (Evans, 2009).

Persentase lapangan kerja industri kreatif subsektor kuliner di Kota Madiun adalah 19\%. Berdasarkan data Dinas Perindustrian Kota Madiun tahun 2016, terdapat 53 industri kuliner khas Kota Madiun yang terdiri dari 41 industri sambel pecel, 5 industri madumongso dan 7 industri kerupuk puli. Industri kuliner merupakan salah satu jenis industri yang mendominasi di Kota Madiun. Hal ini didukung dengan tingginya nilai produksi industri kuliner di Kota Madiun, yaitu sebesar 11 miliar rupiah tiap tahun dan menjadikan industri kuliner sebagai peringkat pertama dalam kategori nilai produksi. Sehingga Kota Madiun termasuk dalam kategori siap. Berikut ini adalah hasil perhitungan persentase tenaga kerja industri kreatif subsektor gastronomi di Kota Madiun dihitung berdasarkan rumus:

Kesiapan kontribusi industri kuliner terhadap penyerapan tenaga kerja dapat dilihat dari persentase jumlah tenaga kerja industri kreatif subsektor kuliner terhadap jumlah tenaga kerja sektor industri. Apabila persentasenya lebih dari 40\%, maka kota tersebut termasuk dalam kategori siap (Evans, 2009).

Kota Madiun termasuk dalam kategori cukup siap karena persentase jumlah tenaga kerja industri kuliner hanya sebesar $11,44 \%$. Industri kuliner di Kota Madiun sebagian besar termasuk dalam jenis industri rumah tangga, sehingga penyerapan tenaga kerja hanya sedikit.

\subsubsection{Kesiapan Kemudahan Pemanfaatan Bahan Baku Lokal Bagi Industri Kuliner}

Kemudahan pemanfaatan bahan baku lokal dilihat dari asal bahan baku dan tingkat aksesibilitas jalan yang dilalui untuk mendapatkan bahan baku tersebut. Kota dapat dikatakan siap dalam penerapan konsep kota kreatif gastronomi apabila industri kuliner mendapatkan bahan baku dari dalam kota dan tingkat aksesibilitas jalan yang dilalui kurang dari 1 (UNESCO, 2004).

Seratur persen industri kuliner di Kota Madiun mendapatkan bahan baku dari dalam Kota Madiun, yaitu dari Pasar Besar Kota Madiun dan toko kelontong yang berada di dekat lokasi industri kuliner. Berdasarkan survei yang telah dilakukan, tingkat kejenuhan jalan yang dilalui untuk mendapatkan bahan baku industri kuliner sebesar 0,69 (kurang dari 1). Sehingga Kota Madiun termasuk dalam kategori siap. Gambar 2 merupakan peta dari jalan yang dilalui pelaku industri untuk mendapatkan bahan bahu lokal berdasarkan tingkat derajat kejenuhannya. 


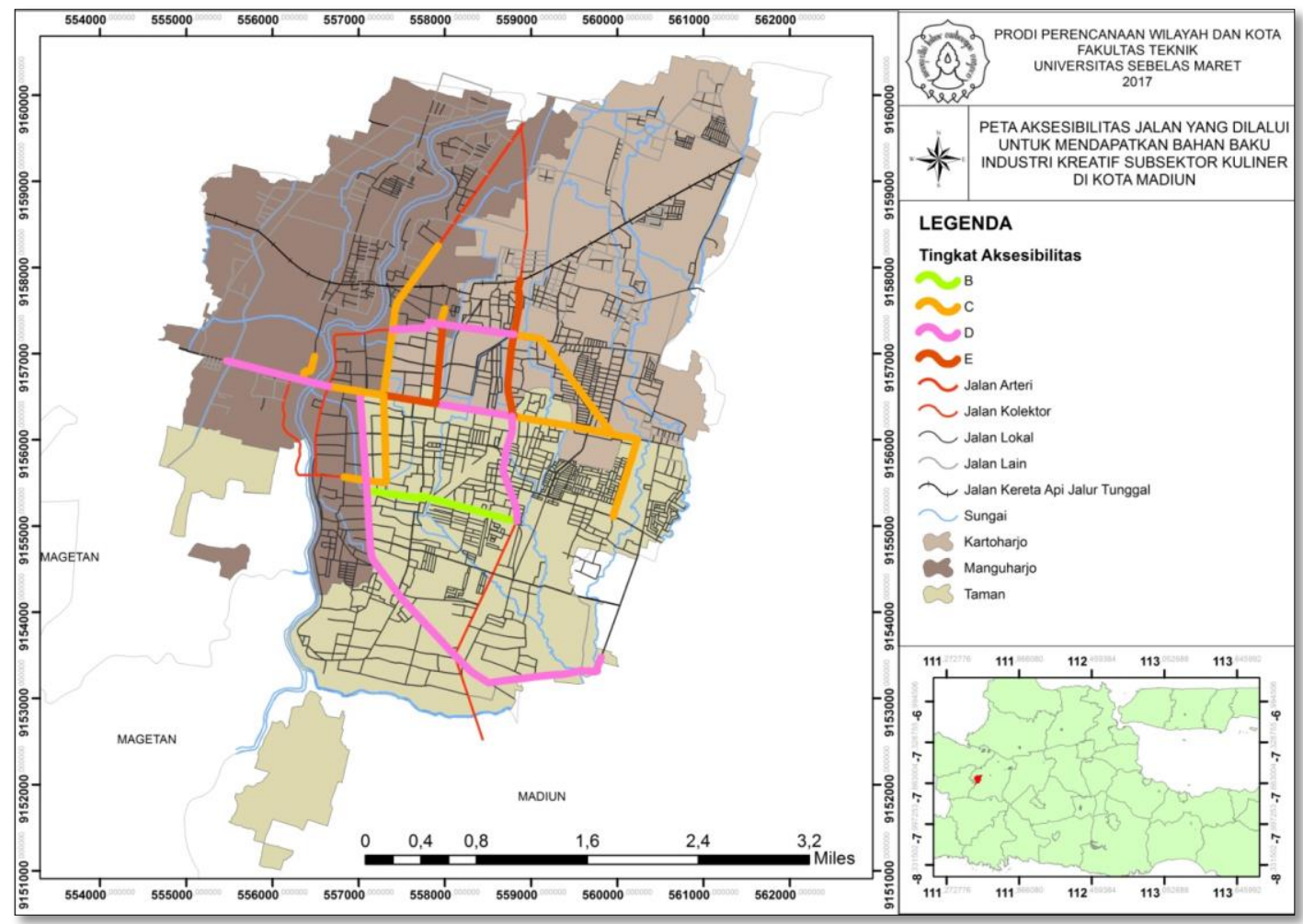

Gambar 2. Peta Tingkat Aksesibilitas Jalan yang Dilalui Untuk Mendapatkan Bahan Baku

\subsection{KESIAPAN KOMUNITAS KREATIF}

\subsubsection{Kesiapan Keberadaan Kelompok Masyarakat, Lembaga Pemerintah dan Lembaga Swasta dalam Pengembangan Kota Kreatif}

Suatu kota dapat dikatakan siap dalam penerapan konsep kota kreatif gastronomi apabila terdapat tiga jenis kelompok kreatif yang aktif dalam pengembangan kota, yaitu lembaga pemerintah, lembaga swasta dan paguyuban masyarakat (UNESCO,2004). Menurut Lopez (2014), kesiapan kota dalam penerapan konsep kota kreatif didukung dengan adanya lembaga, asosiasi dan yayasan yang aktif mengembangan kota. Landry (2006) menjelaskan bahwa kota kreatif harus memiliki kelompok/lembaga masyarakat yang aktif pengembangan kota kreatif gastronomi.

Kota Madiun termasuk dalam kategori cukup siap karena sudah ada lembaga pemerintah dan paguyuban masyarakat yang berperan dalam pengembangan kota kreatif gastronomi. Paguyuban di bidang kuliner di Kota Madiun di antaranya adalah Koperasi Sambel Pecel, FBB (Forum Berbagi, Bersama, dan Berkembang) dan Paguyuban Pengusaha Lempeng. Paguyuban masyarakat ini berperan untuk membantu meminjamkan modal bagi para anggotanya supaya mampu untuk mengembangkan produk. Lembaga pemerintah yang aktif dalam pengembangan kota kreatif gastronomi di Kota Madiun adalah Dinas Ketenagakerjaan Bidang Industri, Dinas Kebudayaan dan Pariwisata Kota Madiun, Dinas Perdagangan, dan BAPPEDA. Sedangkan lembaga swasta yang terlibat dalam pengembangan kota kreatif gastronomi di Kota Madiun masih belum ada.

\subsubsection{Kesiapan Penduduk Usia Muda}

Suatu kota kreatif perlu untuk mengembangkan inovasi dalam pembentukan lingkungan kreatif yang mampu menarik banyak penduduk usia muda (Florida,2005). Komunitas kreatif merupakan punduduk yang memiliki usia muda, yaitu sekitar 15-24 tahun (piramida penduduk stasioner). Hal ini dikarenakan pada usia muda, kreatifitas ataupun ide-ide dapat tersalurkan dengan baik (Landry, 2006). Gambar 3 adalah gambar piramida penduduk di Kota Madiun pada tahun 2016. 


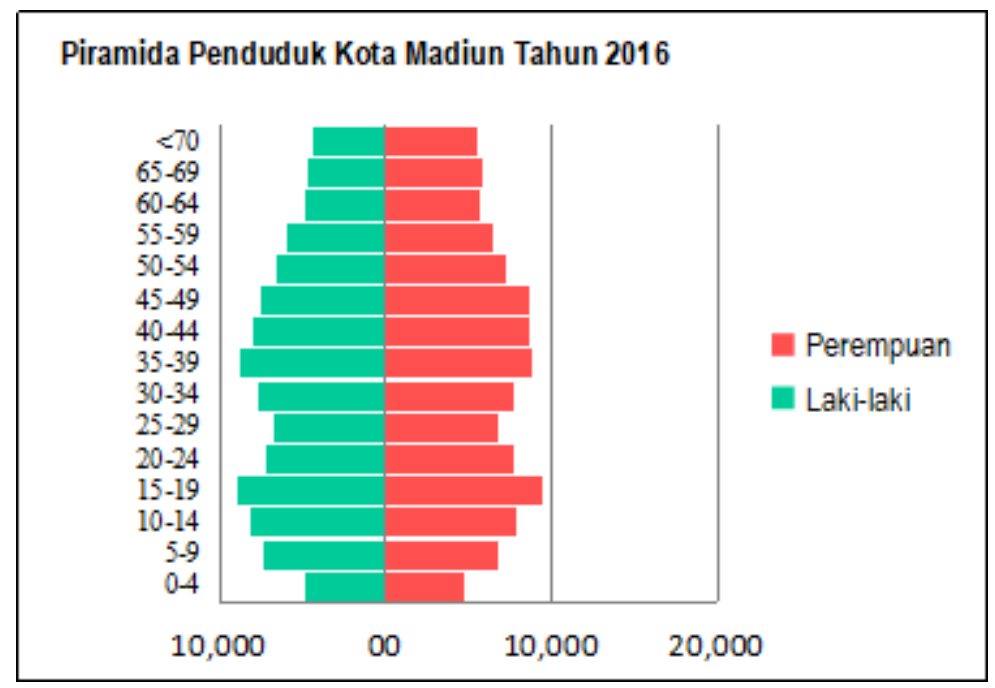

Gambar 3. Piramida Penduduk Kota Madiun Tahun 2016

Bentuk piramida penduduk di Kota Madiun merupakan piramida stasioner. Pada piramida stasioner ini, penduduk usia 1519 jumlahnya yang paling banyak, dimana penduduk tersebut merupakan penduduk usia kerja. Semakin banyak jumlah penduduk usai kerja, maka semakin tinggi juga tenaga kerja yang dimiliki suatu kota. Sehingga Kota Madiun termasuk dalam kategori siap.

\subsection{KESIAPAN LINGKUNGAN KREATIF}

Lingkungan kreatif dalam kota kreatif adalah ketersediaan infrastruktur sosial yang mampu melayani aktivitas kreatif (Florida, 2005). Kesiapan lingkungan kreatif dilihat dari ketersediaan fasilitas pemasaran yang terdiri dari pasar tradisional, pusat oleh-oleh dan restoran tradisional (UNESCO,2004) serta fasilitas pengembangan yang terdiri dari taman, museum dan tempat pelatihan (Landry 2006).

Di Kota Madiun hanya fasilitas pemasaran yang telah tersedia secara lengkap yaitu 12 pasar tradisional, 9 pusat oleholeh dan 20 restoran tradisional. Fasilitas pemasaran ini berperan dalam mempromosikan dan memasarkan kuliner khas Kota Madiun ke daerah luar. Sedangkan fasilitas pengembangannya hanya terdapat 4 taman yang berperan sebagai ruang yang mampu memfasilitasi terciptanya inovasi guna memunculkan ide-ide baru dalam meningkatkan nilai jual produk. Berdasarkan uraian di atas, Kota Madiun termasuk dalam kategori tidak siap karena ketersediian fasilitas pengembangan yang masih belum lengkap. Padahal dalam mengembangakan kota kreatif gastronomi penting untuk suatu kota memiliki baik fasilitas pemasaran maupun fasilitas pengembangan. Gambar 4 adalah peta persebaran fasilitas pemasaran di Kota Madiun. 


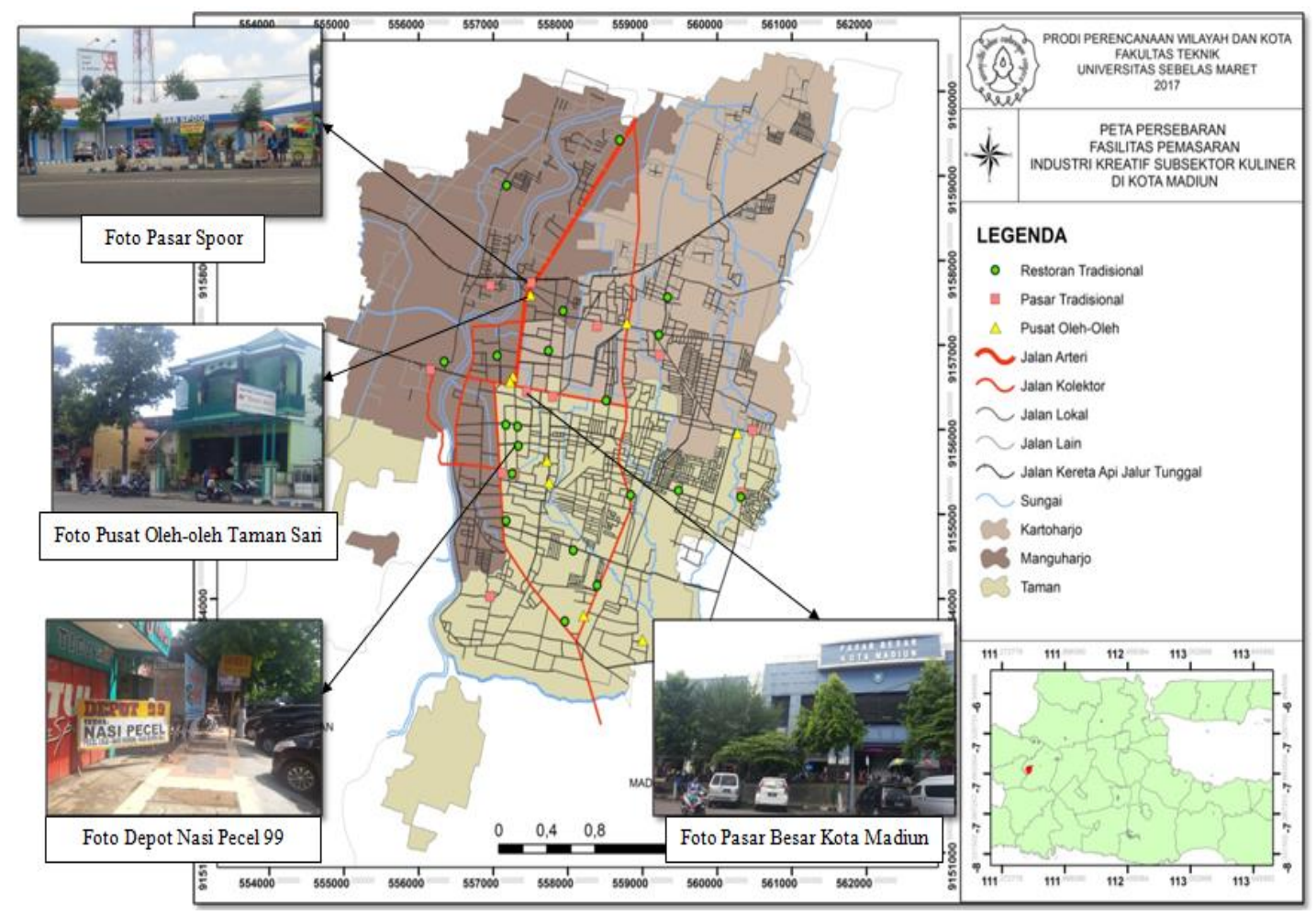

Gambar 4. Peta Persebaran Fasilitas Pemasaran Kota Kreatif Gastronomi Madiun

Gambar 5 adalah peta persebaran fasilitas pengembangan di Kota Madiun.

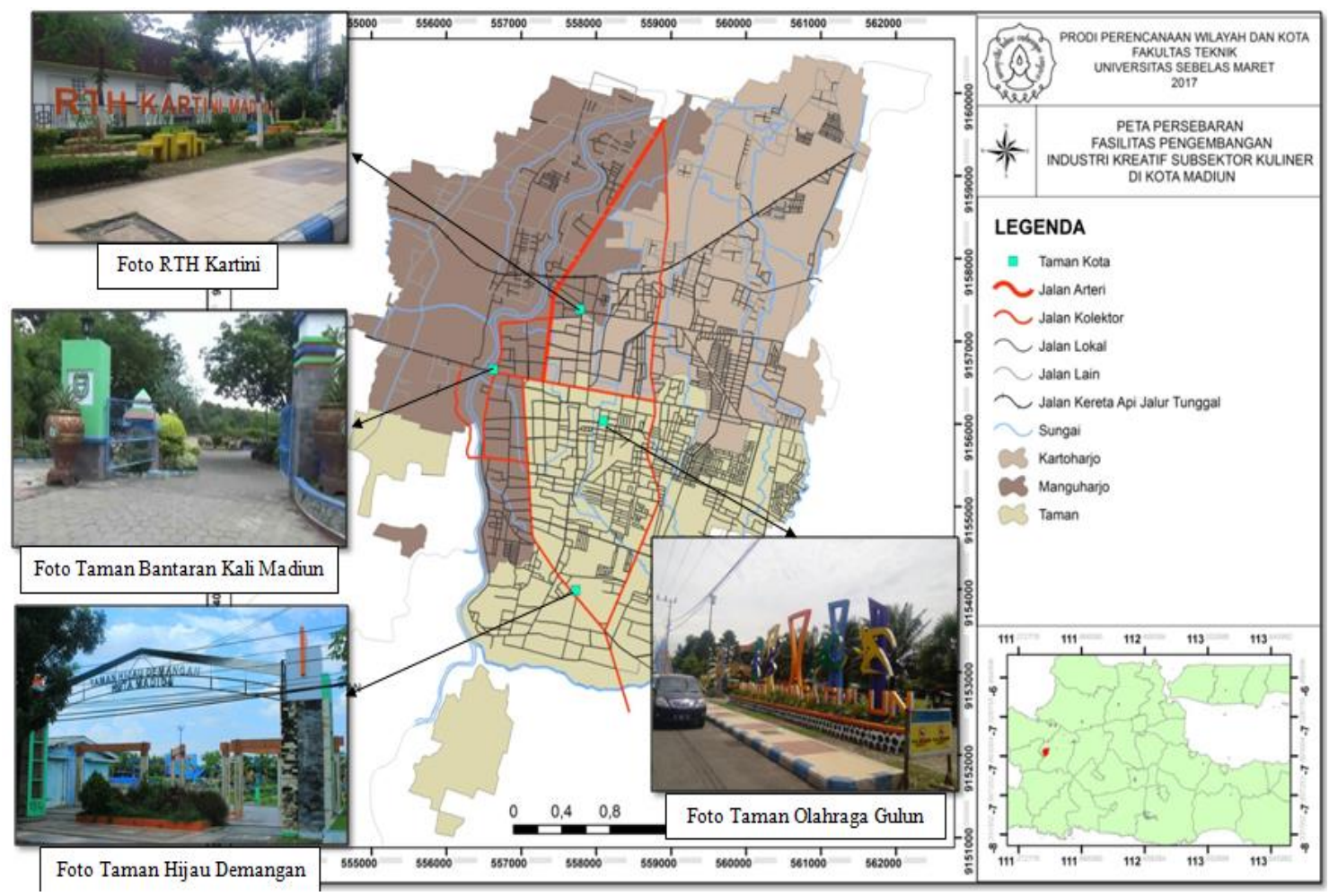

Gambar 5. Peta Persebaran Fasilitas Pengembangan Kota Kreatif Gastronomi Madiun 


\subsection{KESIAPAN KEBIJAKAN}

\subsubsection{Kesiapan Rencana}

Pengembangan kota kreatif gastronomi harus memiliki rencana yang memuat empat komponen kota kreatif yaitu industri kreatif, lingkungan kreatif, komunitas kreatif dan kebudayaan lokal (Landry, 2006). Menurut Lopez (2014) kota kreatif harus memiliki kebijakan dalam pengembangan kota gastronomi. Dalam mencapai kesiapan pengembangan kota kreatif, rencanarencana dari keempat aspek kota kreatif harus tuntas/terlaksana. Gambar 6 dan Gambar 7 adalah diagram pie persentase rencana pengembangan dan ketuntasan rencana.

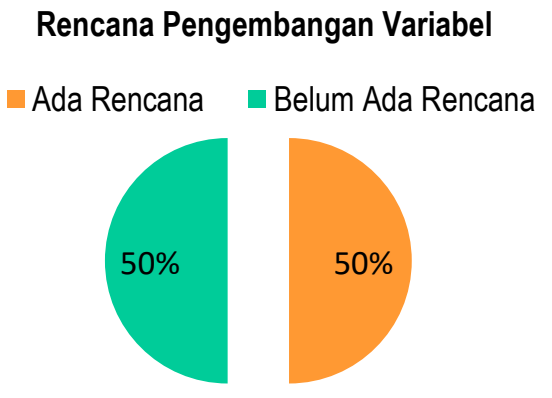

Gambar 6. Diagram Persentase Rencana Pengembangan

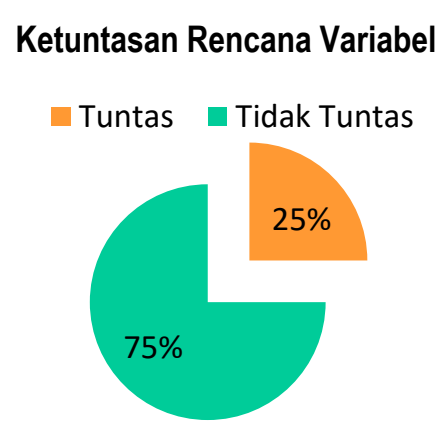

Gambar 7. Diagram Persentase Ketuntasan Rencana

Sesuai dengan Gambar 6, terdapat 50\% atau dua komponen kota kreatif gastronomi di Kota Madiun yaitu ekonomi kreatif, dan lingkungan kreatif telah memiliki rencana pengembangan, namun untuk komponen komunitas kreatif dan kebudayaan lokal masih belum keseluruhan indikatornya memiliki rencana pengembangan. Ketuntasan rencana dari masing-masing komponen juga masih ada yang belum tuntas, yaitu sebesar $75 \%$ sesuai dengan Gambar 7 . Kondisi ini menyebabkan industri kuliner di Kota Madiun masih belum secara maksimal mendapat dukungan pemerintah dalam mengembangankan industri. Sehingga Kota Madiun termasuk dalam kategori tidak siap.

\subsubsection{Kesiapan Kemitraan}

Suatu kota dianggap siap menjadi kota kreatif jika kemitraan dinaungi oleh tiga jenis stakeholder (public, private, dan voluntary) (Landry, 2006). Menurut Lopez (2014) dalam pengembangan kota kreatif harus didukung dengan adanya kemitraan antara publik dan swasta.

Di Kota Madiun kemitraan dalam pengembangan kota kreatif gastronomi terdiri dari dua stakeholder yang berperan, yaitu pemerintah (public), Bank dan Pebisnis (private) dengan peran masing-masing. Pemerintah berperan dalam pembuatan kebijakan dan pelaksanaan program guna mendukung pengembangan kota kreatif. Bank dan pebisnis (pusat oleh-oleh) berperan dalam bantun peminjaman modal dan pemasaran produk. Dalam pengembangan kota kreatif, Pemerintah Kota Madiun mengadakan kerjasama dengan Bank Perkreditan Rakyat (BPR). Kerjasama ini dilakukan untuk memudahkan pemilik industri dalam mendapatkan pinjaman modal dengan bunga 0,5\%. Selain itu, kerjasama juga dilakukan oleh pemilik industri dengan pemilik toko oleh-oleh guna membantu dalam pemasaran produknya. Sehingga Kota Madiun termasuk dalam kategori cukup siap.

\subsection{KESIAPAN KEBUDAYAAN LOKAL}

\subsubsection{Kesiapan Sejarah Kota di Bidang Kuliner}

Sebuah kota harus bisa menyeimbangkan kebudayaan modern yang masuk dengan nilai-nilai lokal. Jika identitas lokal terlalu banyak terkikis, maka kota akan kehilangan ciri khas dan dasar pendiriannya (Florida, 2005) . Oleh karena itu, dalam pengembangan kota kreatif harus dibangun dengan tujuan memperkuat budaya lokal dan mewujudkan kekhasan dari kota tersebut. Sejarah kota terkait dengan kuliner lokal dilihat dari orisinilitas produk tersebut sebagai bagaian dari kebudayaan kota (Landry, 2006). 
Kota Madiun termasuk dalam kategori siap karena ketiga makanan khas Kota Madiun (sambel pecel, madumongso dan kerupuk puli) merupakan makanan khas asli dari Kota Madiun yang telah menjadi warisan budaya lokal dan telah diakui secara nasional. Pemerintah Kota Madiun terus melakukan pelestariaan kuliner lokal tersebut baik dengan mengadakan beberapa event kuliner maupun melakukan pelatihan secara rutin kepada pelaku industri kuliner dan meminjamkan modal untuk mengembangkan usahanya.

\subsubsection{Kesiapan Penyelenggaraan Event Kuliner}

Event merupakan usaha yang dilakukan untuk mempromosikan produk industri kreatif kuliner. Penyelenggaraan event harus diadakan dalam skala internasional agar kota dapat dikenal (Landry, 2006). Dalam kriteria kota kreatif salah satunya adalah pengalaman kota dalam menyelenggarakan event yang dilakukan untuk promosi potensi kuliner lokal (UNESCO, 2004).

Tabel 2. Event Kuliner di Kota Madiun

\begin{tabular}{lcc}
\multicolumn{1}{c}{ Nama Event } & Skala & Event Tahunan \\
\hline Bazar Takjil Ramadhan & Lokal & $\sqrt{ }$ \\
Pameran Hari Jadi Kota Madiun & Lokal & $\sqrt{ }$ \\
Pameran Produk Unggulan IKM/ UKM Kota Madiun & Nasional & $\sqrt{ }$ \\
\hline
\end{tabular}

Event kuliner tahunan yang diselenggarakan di Kota Madiun berskala nasional (lihat Tabel 2). Event tahunan bazar takjil ramadhan merupakan suatu event yang rutin diselenggarakan Pemerintah Kota Madiun selama lima hari di Bulan Ramadhan. Event pameran hari jadi Kota Madiun diadakan untuk memperingati ulang tahun Kota Madiun yang diselenggarakan di Alunalun Kota Madiun. Peserta pameran ini adalah semua jenis produk unggulan Kota Madiun. Pameran Produk Unggulan IKM/ UKM Kota Madiun diselenggarakan oleh Pemerintah Kota Madiun setiap tahunnya di Alun-alun Kota Madiun. Sehingga Kota Madiun termasuk dalam kategori cukup siap. Gambar 9 adalah peta persebaran event kuliner di Kota Madiun.

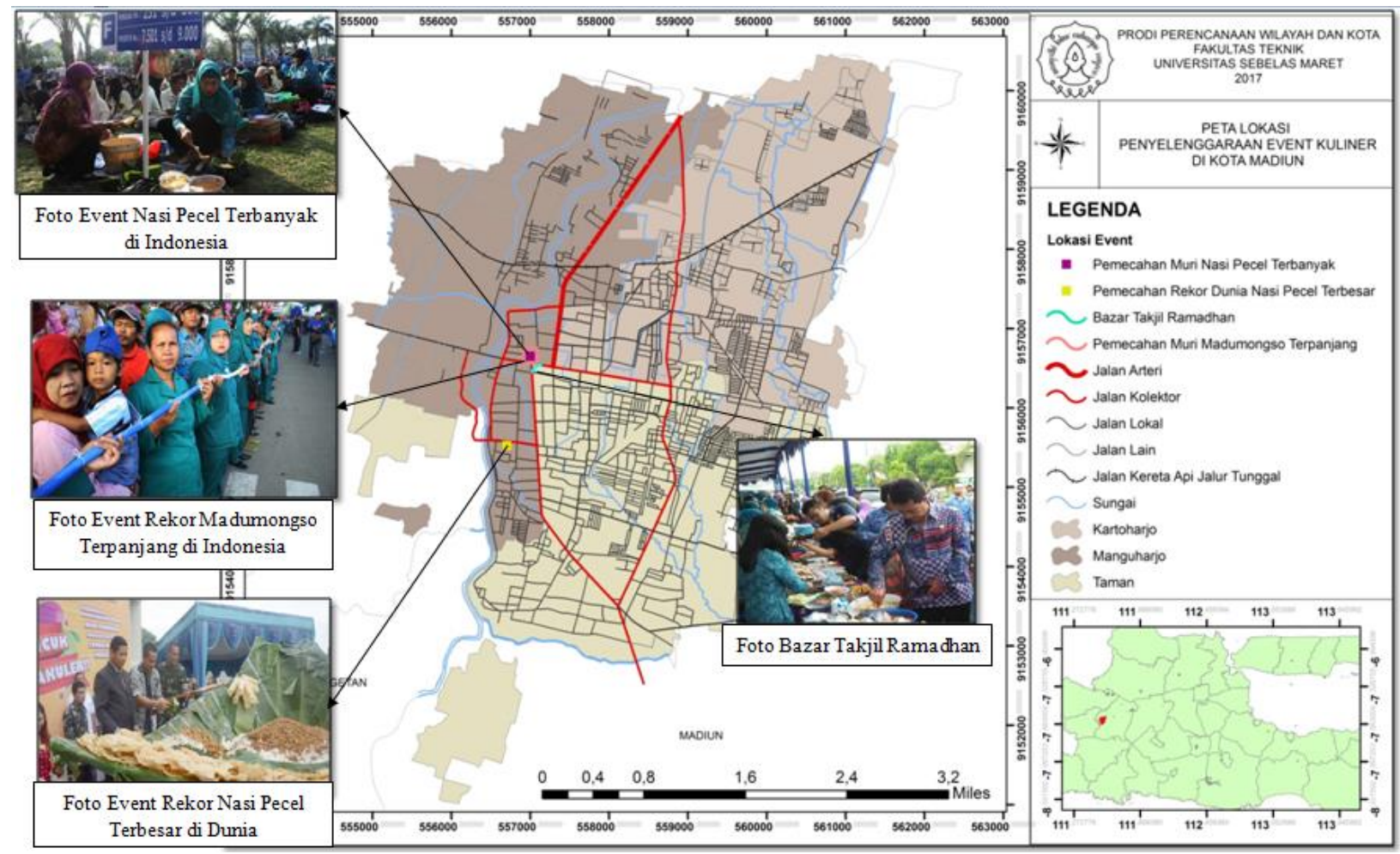

Gambar 9. Peta Lokasi Penyelenggaraan Event Kuliner 


\subsubsection{Kesiapan Partisipasi Masyarakat}

Partisipasi masyarakat dapat diperoleh ketika mereka sendiri merasa terlibat dan merasakan manfaatnya langsung dari kegiatan atau proyek yang melibatkan mereka (Landry, 2006). Gambar 10 dan Gambar 11 adalah diagram pie partisipasi penduduk Kota Madiun dalam mengembangkan kota kreatif.

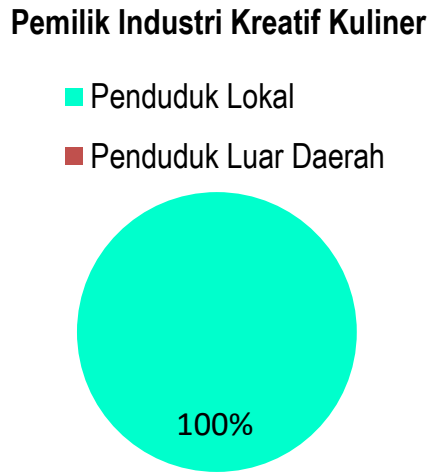

Gambar 10. Diagram Pemilik Industri Kuliner

\section{Tingkat Partisipasi dalam \\ Penyelenggaraan Event}

- Berpartisipasi $\quad$ Tidak Berpartisipasi

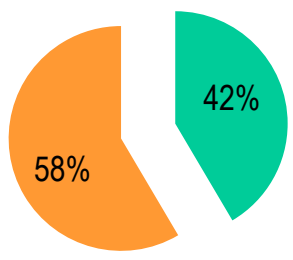

\section{Gambar 11. Diagram Tingkat Partisipasi Masyarakat}

Partisipasi masyarakat Kota Madiun termasuk dalam kategori cukup siap. Seratus persen pemilik industri kuliner merupakan penduduk asli Kota Madiun. Pelaku industri kuliner di Kota Madiun sebagian besar merupakan penerus dari keluarga mereka yang sebelumnya mendirikan industri tersebut. Mereka mau untuk meneruskan usaha keluarga tersebut karena melihat masih tingginya peluang untuk industri sambel pecel, madumongso dan kerupuk puli untuk terus bertahan. Apalagi permintaan produk kuliner khas Kota Madiun tidak hanya berasal dari dalam kota, namun juga dari luar kota. Keikutsertaan pelaku industri dalam pameran sangat penting untuk mengembangan kota kreatif karena dapat dijadikan sebagai tempat promosi produk unggulan mereka. Pelaku industri kuliner di Kota Madiun sebagian besar belum ikut berpartisipasi dalam penyelengaraan event yaitu sebesar $42 \%$.

Dari hasil skoring tiap variabel kemudian dilakukan analisis untuk mengetahui kesiapan Kota Madiun terhadap penerapan konsep kota kreatif gastronomi. Gambar 12, Gambar 13, Gambar 14, Gambar 15, Gambar 16 merupakan diagram batang skoring tiap variabel.

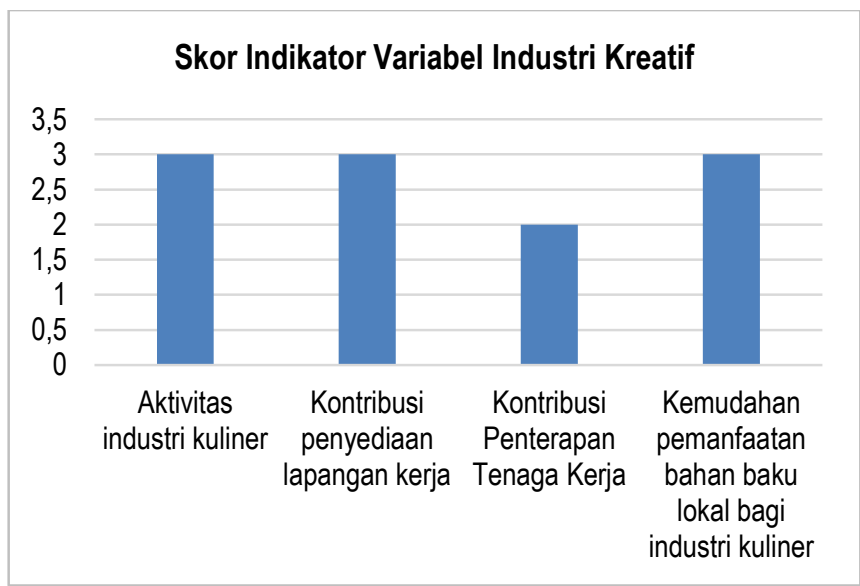

Gambar 12. Diagram Batang Skor Indikator Industri Kreatif

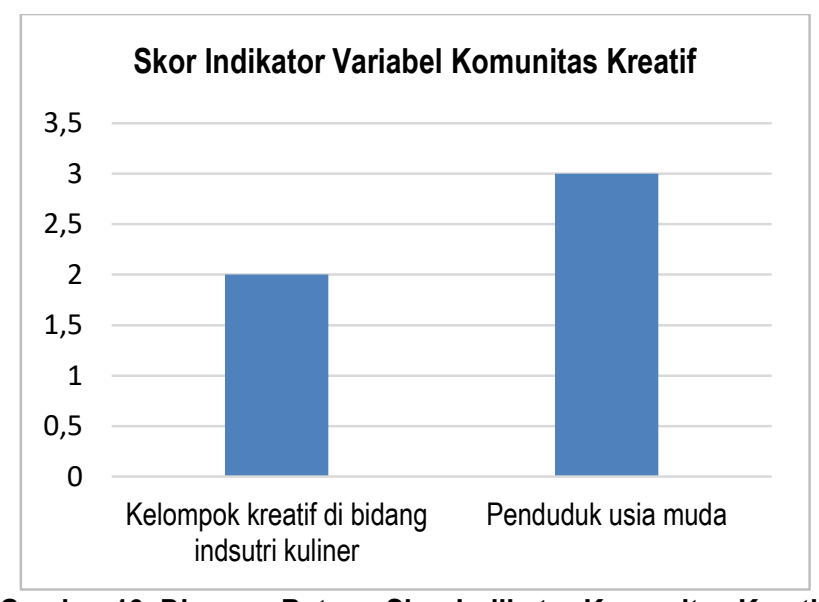

Gambar 13. Diagram Batang Skor Indikator Komunitas Kreatif 


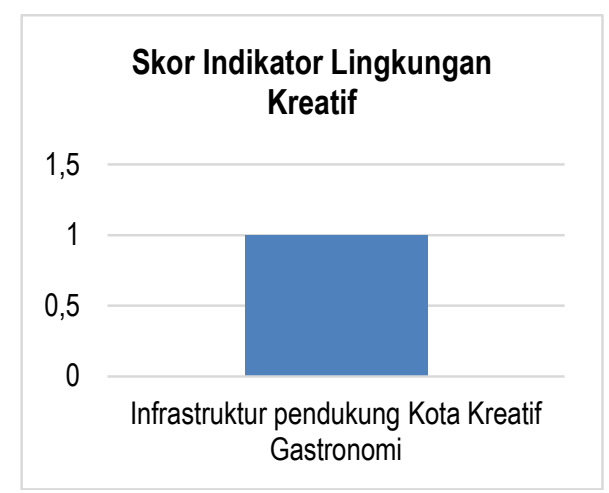

Gambar 14. Diagram Batang Skor Indikator Lingkungan Kreatif

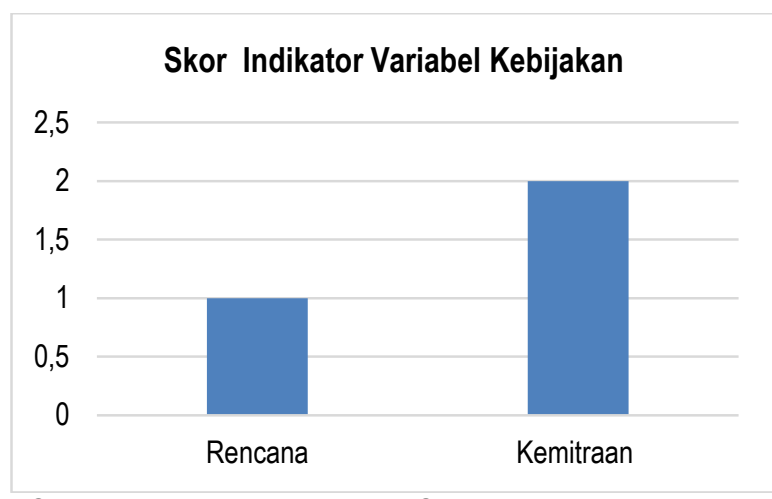

Gambar 15. Diagram Batang Skor Indikator Kebijakan

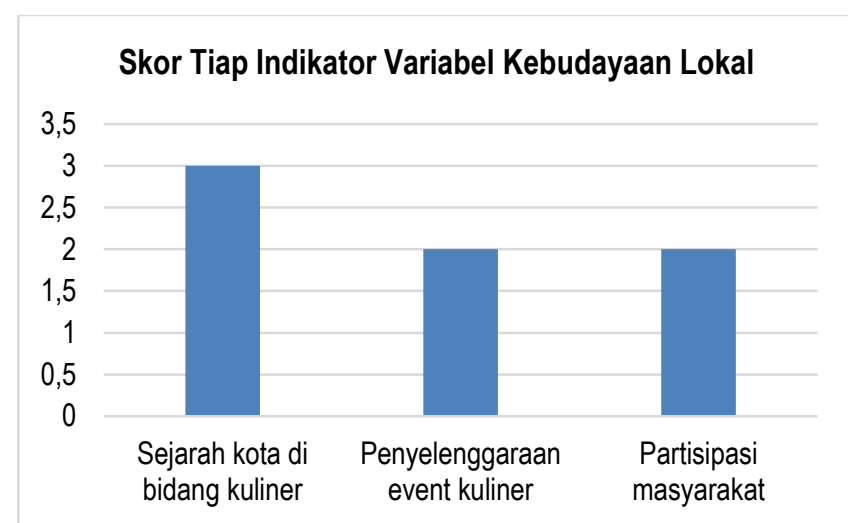

Gambar 16. Diagram Batang Skor Indikator Kebudayaan Lokal

Dari skoring pada masing-masing indikator variabel tersebut lalu dijumlahkan hingga mendapat skor untuk masing-masing variabelnya sesuai dengan Tabel 1. Gambar 17 adalah hasil skoring masing-masing variable.

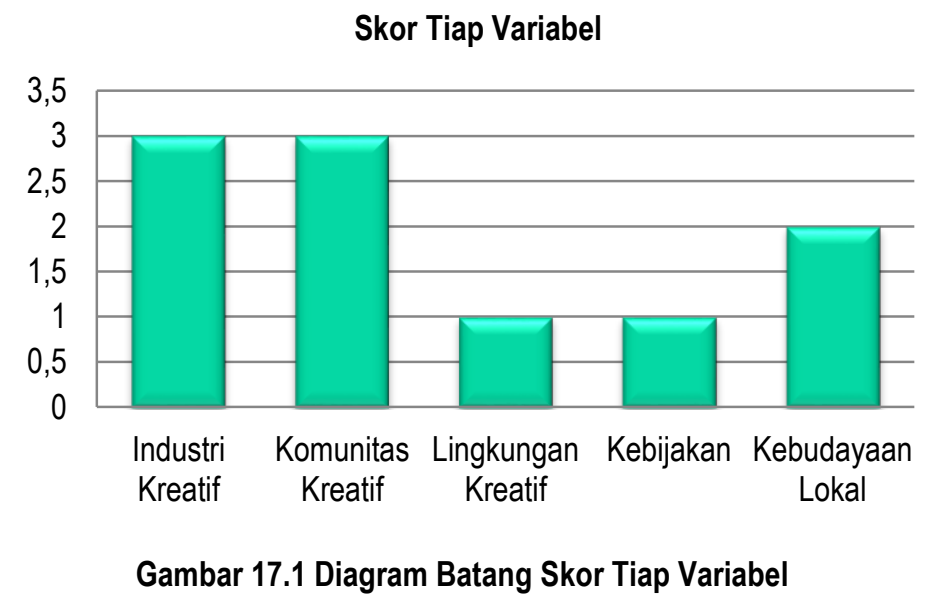

Dari hasil penjumlahan skor tiap variabel secara keseluruhan tingkat kesiapan Kota Madiun terhadap penerapan konsep kota kreatif gastronomi adalah 10, indikator tersebut menunjukkan bahwa Kota Madiun cukup siap dalam penerapan Kota Kreatif Gastronomi. Berdasarkan analisis terdapat dua variabel yang mendapat nilai 3 yang termasuk dalam kategori siap, yaitu industri kreatif dan komunitas kreatif namun kesiapan kedua variabel tersebut tidak di imbangi dengan lingkungan kreatifnya yang hanya mendapat nilai 1 dan termasuk dalam kategori tidak siap. Sedangkan variabel kebijakan dan kebudayaan lokal masing-masing mendapat nilai 2 dan termasuk dalam kategori cukup siap 


\section{KESIMPULAN}

Dari hasil penjumlahan skor tiap variabel secara keseluruhan tingkat kesiapan Kota Madiun terhadap penerapan konsep kota kreatif gastronomi menunjukkan bahwa Kota Madiun cukup siap. Berdasarkan analisis terdapat dua variabel yang mendapat nilai 3 yang termasuk dalam kategori siap, yaitu industri kreatif dan komunitas kreatif. Namun kesiapan kedua variabel tersebut tidak di imbangi dengan lingkungan kreatifnya yang hanya mendapat nilai 1 dan termasuk dalam kategori tidak siap. Sedangkan variabel kebijakan dan kebudayaan lokal masing-masing mendapat nilai 2 dan termasuk dalam kategori cukup siap. Ketidaksiapan variabel-variabel tersebut disebabkan oleh kurangnya dukungan pemerintah dan pelaku industri untuk menciptakan lingkungan kota yang mampu mengembangkan ide-ide penduduk Kota Madiun dalam penerapan konsep kota kreatif gastronomi.

\section{DAFTAR PUSTAKA}

Chengdu City of Gastronomy. (2012). Reviewing Report on City of Gastronomy Chengdu China. Chengdu: Chengdu City of Gastronomy. Diakses dari https://en.unesco.org/creative-cities/sites/creative-cities/files/EvaluationReport_Chengdu.pdf

Evans, G. (2009). Creative Cities. Creative Space and Urban Policy. SAGE Journals, 46(5-6), 1003-1040. DOI: $10.1177 / 0042098009103853$

Florida, R. (2005). Cities and The Creative Class, City \& Community, 2(1), 3-19. Diakses dari http://www.estudislocals.cat/wpcontent/uploads/2016/11/4-Cities-and-the-Creative-Class.pdf

Gilleisole. (2001). Psikologi Umum. Bandung: Bumi Aksara

KIM Bakti Pertiwi. (2016, April 12). Kota Madiun Menuju Kota Kreatif. Diakses dari http://kimbhaktipertiwi.blogspot.com/2016/04/vbehaviorurldefaultvmlo.html

Landry, C. (2000). The Creative City: A Toolkit for Urban Innovator. London: Earthscan.

Landry, C. (2006). The Art of City- Making, Journal Australian Planner, 43(4), 47. DOI: 10.1080/07293682.2006.9982528

Lopez-Guzman, T., Hernandez-Mogollon, J. M. \& Clemente, E. D. (2014). Gastronomic Tourism as an Engine For Local and Regional Development, EconPapers, 14(1), 95-104. Diakses dari https://www.usc.gal/economet/reviews/eers1417.pdf

Pratt, A. (2008). Creative cities: Tensions within and between social, cultural and economic development. City, Culture and Society, 1, 1320. DOl: : $10.1016 /$ j.ccs.2010.04.001

Sugiyono. (2015). Metode Penelitian Pendidikan (Pendekatan Kuantitatif, Kualitatif dan R\&D). Bandung: CV. Alfabeta

UNESCO Creative City Network (2004). Creative Cities Network. Diakses dari http://en.unesco.org/creative-cities/

Vickery, J. (2011). Beyond the Creative City - Cultural Policy in an age of scarcity. Birmingham: University of Warwick. Diakses dari http://made.org.uk/media/files/BeyondtheCreativeCity.pdf

Wibisono, R. (2015). INDUSTRI KREATIF : Di Madiun, Madumongso dan Sambal Pecel Dianggap Produk Ekonomi Kreatif. Diakses dari https://www.madiunpos.com/industri-kreatif-di-madiun-madumongso-dan-sambal-pecel-dianggap-produk-ekonomi-kreatif-663642 